\title{
Tom, Dick \& Harry
}

\section{Craig Batty}

School of Creative Arts Film and Media, University of Portsmouth, UK (craig.batty@port.ac.uk)

doi: $10.2167 /$ new290.0

\section{FADE IN:}

\section{BLACK}

The sound of heavy breathing coming from a man (JAVEEV). Panting. Sounds like sex.

$$
\text { JAVEEV }
$$

Oh yeah baby ... oh yeah...

More panting. Starts to get breathless.

$$
\text { (v/o) JAVEEV }
$$

Almost there... just a bit harder... one more tug...

As the pace gets faster, JAVEEV explodes. Sounds like he has come.

\section{QUICK CUT TO:}

\section{EXT. ALLOTMENT - DAY}

JAVEEV, mid twenties, Asian, a looker, lays on the ground sweating. He has just pulled out a very old, decaying marrow that has a very long root.

He picks up the marrow and looks at the root.

JAVEEV

\section{Prehistoric or what?!}

As he begins to stand, neighbouring allotment holders TOM, DICK and HARRY approach.

\section{TOM}

Aye, aye, what do we have here? 
DICK

Must be the new 'un.

JAVEEV

Gentlemen, hello. Javeev.

JAVEEV wipes his hand on his jeans and offers it to shake with TOM, DICK and HARRY.

\section{HARRY}

P-p-pleased to meet you.

\section{DICK}

Good on you. Diversity an' all.

JAVEEV frowns.

TOM

We're very open minded.

(beat)

And the wife does a lovely chicken Korma.

JAVEEV reacts - 'I see... going to be like this.'

TOM

I'm Tom.

\section{DICK}

Richard - but you can call me Dick.

Harry.

\section{HARRY}

(beat)

It is a b-b-bit of a shock to see

someone so da-dar-dar-darn young

taking Pete's place...

\section{DICK}

Bless his soul.

\section{HARRY}

... but b-b-be-be ...good luck.

JAVEEV smiles.

TOM

(re: marrow)

Looks like you'll have quite a bit of work on your hands. 


\section{Nearly killed me.}

JAVEEV

HARRY nearly chokes. DICK pats him on the back.

\section{DICK}

That's how they found Pete.

Just there. Marrow in one hand, tissue in the other.

\section{TOM}

Never did work out who called the ambulance.

JAVEEV seems quite disturbed; awkward. Then ...

$$
\text { JAVEEV }
$$

Come inside.

They all head to JAVEEV's shed.

\section{TOM}

It'll be good to get some fresh blood around here.

\section{DICK}

Out with the old, in with the new.

$$
\text { JAVEEV }
$$

My sentiments exactly.

\section{INT. JAVEEV'S SHED - DAY}

A swish looking, large, green compost bin stands in the corner.

TOM, DICK, HARRY and JAVEEV are enjoying a cup of tea.

TOM

We've never had any Indians around here before.

$$
\text { JAVEEV }
$$

I'm not Indian.

\section{DICK}

No blacks at all, actually.

JAVEEV reacts - 'Here we go again...' 
TOM

Bringing in new ways of growing things... new smells... I think it's marvellous.

JAVEEV stands. He pats the large green compost bin.

\section{JAVEEV}

This is the only new thing to watch around here.

They all look, baffled.

\section{JAVEEV}

It's got super powers. A special recipe.

(taps his nose)

Sworn to secrecy.

\section{HARRY}

Bit of a t-t-to-tos-tease, aren't you?

$$
\begin{gathered}
\text { JAVEEV } \\
\text { (smirking) } \\
\text { That's what my boyfriend says. }
\end{gathered}
$$

HARRY drops his cup.

\section{DICK}

Come on, we're not going to...

[copy.] Sorry, did you just say...

[boyfriend]?

TOM

What did he say?

DICK

I think he said boyfriend.

HARRY

He d-d-d... [did.]

JAVEEV

I did.

Stunned silence. TOM, DICK and HARRY don't know what to say or where to look. Suddenly... 
TOM

Best be off then.

DICK

Million and one things to do.

They dash out of the shed. HARRY tries to smile but he can't.

\author{
JAVEEV \\ Hang on a minute. \\ DICK \\ (remote) \\ I've changed my mind - you can \\ call me Richard.
}

And they're gone. JAVEEV is defeated, deflated. He looks at the compost bin.

EXT. ALLOTMENT - DAY (a few days later)

JAVEEV is looking at a poster advertising the annual marrow competition. On the poster, images of giant, green, ripe marrows.

JAVEEV lowers the poster to reveal the allotment as it is: decaying, brown, in need of much work.

Over on their plots, TOM, DICK and HARRY try to keep their heads down and ignore JAVEEV.

\title{
DICK
}

Poofs. Bloody poofs. Not even

English poofs.

TOM

They don't know how to work the land.

JAVEEV calls over from his plot, friendly.

\section{JAVEEV}

I take it you've got the ad for the competition?

Silence. Then ...

$$
\text { JAVEEV }
$$

Stand a good chance, I reckon. 
TOM and DICK seethe as they continue to ignore him. HARRY seems stuck in the middle.

\section{TOM}

Trust it to be a marrow. Of all

the bloody vegetables. Poof. Marrow.

I ask you.

\section{DICK}

Even radishes would be rubbing salt into $t^{\prime}$ wounds.

HARRY frowns - he doesn't see the allusion.

Over on his plot, JAVEEV is again defeated. He sighs; has made a decision.

$$
\begin{aligned}
& \text { JAVEEV } \\
& \text { (to himself) }
\end{aligned}
$$

It didn't have to be like this.

Back over on their plots...

\section{It's not on.}

\section{DICK}

TOM stops his work and looks over to JAVEEV, who is turning over the soil, making a real effort.

\section{TOM}

No, it's not.

(beat)

Something's got to be done.

\section{EXT. ALLOTMENT - NIGHT}

It is dark. TOM is wearing all black. He has a torch and scurries cautiously over to JAVEEV's shed.

TOM holds up a bottle - the label reads ' $X$ - extremely poisonous.' He smirks.

He opens the shed door and tiptoes inside.

The shed door slowly creeks shut after him.

EXT. ALLOTMENT - DAY (a week later)

JAVEEV's plot is now looking a lot healthier. He smiles as he shovels compost from the large green bin onto the soil. 
TOM's plot is starting to overgrow. DICK and HARRY look concerned.

\section{DICK}

I don't know where the hell he could have got to.

\section{HARRY}

It's not like him. Puts his 1-1-life and s-s-soul into this plot.

\section{DICK}

Probably put off by yond over there.

As DICK and HARRY look over, JAVEEV waves, cheery.

\section{JAVEEV}

Still no sign of Tommy boy?

$$
\text { (sharp) }
$$

He's biding his time.

\section{JAVEEV}

$\mathrm{He}^{\prime} \mathrm{d}$ better put a spurt on if he wants to win this competition. My marrows are growing faster than you can say... well, marrow!

JAVEEV laughs.

DICK and HARRY turn away, sneeringly, picking up their spades.

\section{DICK}

It's all a put on.

\section{HARRY}

I don't know, they are q-q-quite big already.

\section{DICK}

We'll soon see to that.

He slams his spade into the soil.

\section{EXT. ALLOTMENT - EVENING}

It is dusk. The allotments are still. DICK comes out of his shed with a crowbar and a bottle of insecticide. 
He cautiously makes his way over to JAVEEV's shed and crowbars the lock open. He takes one last look around before he enters the shed.

\title{
INT. JAVEEV'S SHED - EVENING
}

DICK goes over to the large green compost bin and opens the lid.

\section{DICK}

Special recipe indeed.

He unscrews the lid from the bottle of insecticide. Just as he is about to pour it into the compost bin, a noise behind startles him.

He turns. His eyes widen - fear.

EXT. ALLOTMENT - DAY (a month later)

JAVEEV's marrows are now growing big and juicy.

Opposite, both TOM and DICK's plots are very brown, decaying and overgrown.

HARRY is alone, tending to his marrows, polishing them with a cloth. JAVEEV approaches, startling HARRY.

\section{JAVEEV}

It's really strange you know, letting their plots go like that.

\author{
HARRY \\ (suspicious)
}

Very strange.

\section{JAVEEV}

I hope they weren't put off by the success I'm having.

\section{HARRY}

Tom and Dick don't give in to competition. They th-th-thrive on it.

Keeps 'em g-g-going.

JAVEEV

Well where are they?

\section{HARRY}

Good question. A very g-g-good question indeed. 
JAVEEV shrugs his shoulders - 'oh well.' He heads back to his plot, happily, but HARRY hasn't finished...

\section{HARRY}

Like playing games, do you?

\section{JAVEEV}

Harry, darling, the only game I'm interested in is the marrow competition. You know that.

\section{HARRY}

Funny, d-d-don't you think, them going missing?

\section{JAVEEV}

I'm certainly not laughing.

$$
\text { (beat) }
$$

Call it Karma. You reap what you sow.

$$
\text { (beat, smiles) }
$$

So to speak.

HARRY puts down his cloth and hoists himself up.

\section{HARRY}

That soil was almost dead. Look at it now. M-m-marrows like Pete could only dream of.

\section{JAVEEV}

It's my special compost, I did warn you. Come and have a look. (whispering)

If you're a good boy I might even give you a shovel full.

\section{HARRY}

I'm not going anywhere near your sordid shed!

\section{JAVEEV}

Suit yourself.

He wanders off happily, singing 'I Am What I Am.'

HARRY is left feeling very suspicious. 


\section{EXT. ALLOTMENT - NIGHT}

HARRY is sitting on his plot, drinking whiskey, and with a small fire burning. He is looking at a picture of him, TOM and DICK all holding their spades in the allotment.

\section{HARRY}

(sad, to himself)

Where are you?

There is suddenly a soft noise of what sounds like bells. HARRY looks around but sees nothing.

Again, a sound of bells and a whispered 'Harry.'

HARRY stands to investigate, suddenly noticing the mystic figure of a lady in a sari wearing lots of jewellery (it is JAVEEV dressed up).

The figure beckons HARRY over. At first he appears frightened, but then contemplates the idea of going over.

The figure continues to beckon and HARRY begins to amble over.

The figure opens JAVEEV's shed door and glides in. HARRY stops, but continues when 'Harry' is whispered once more.

HARRY enters the shed, the door creaking shut behind him.

A moment, then HARRY lets out a shriek of shock and fear.

DISSOLVE TO:

EXT. ALLOTMENT - DAY (a few weeks later)

JAVEEV stands proud with a gold medal around his neck, and a giant marrow beside him.

Behind, TOM, DICK and HARRY's plots are all overgrown and decaying.

A PHOTOGRAPHER takes pictures of JAVEEV. A REPORTER scribbles in her notebook.

\section{REPORTER}

Tell me, Javeev, what's your secret?

JAVEEV

Don't know if there is one. Just a

very good gardener. 


\title{
REPORTER
}

Come on, even the best have their secrets caches.

\section{JAVEEV}

Well ... let's just say it may be to do with the compost I use.

Special formula. But that's all I'm saying.

\section{REPORTER}

There must be something. Word of wisdom? Where did you get the formula?

$$
\begin{aligned}
& \text { JAVEEV } \\
& \text { (smiling) }
\end{aligned}
$$

Oh, nowhere special. Bits and bobs, here and there.

\section{REPORTER}

Any name you think you should give thanks to?

\author{
JAVEEV \\ Again, no-one special. Perhaps \\ the usual old Tom, Dick or Harry.
}

JAVEEV smiles, beaming with the knowledge that he has won.

As the interview continues, we slowly go up to the shed and to the window.

Through the window we see, standing proud, the large, green compost bin.

END 